\title{
A Systematic Review of Terrestrial Plant Invasion Mechanisms Mediated by Microbes and Restoration Implications
}

\author{
K. Dawkins, J. Mendonca, O. Sutherland, N. Esiobu \\ Microbial Biotech Lab, Florida Atlantic University, Boca Raton, USA \\ Email: dawkinsk2014@fau.edu
}

How to cite this paper: Dawkins, K., Mendonca, J., Sutherland, O. and Esiobu, N. (2022) A Systematic Review of Terrestrial Plant Invasion Mechanisms Mediated by Microbes and Restoration Implications. American Journal of Plant Sciences, 13, 205-222.

https://doi.org/10.4236/ajps.2022.132013

Received: December 21, 2021

Accepted: February 19, 2022

Published: February 22, 2022

Copyright $\odot 2022$ by author(s) and Scientific Research Publishing Inc. This work is licensed under the Creative Commons Attribution International License (CC BY 4.0).

http://creativecommons.org/licenses/by/4.0/

(c) (i) Open Access

\begin{abstract}
Terrestrial invasive plant species continue to wreak havoc on a global economic and ecological scale. With the advent of climate change and pending future catastrophes, the spread of resilient invasive plants will only increase exponentially. Here, the search continues for a better understanding of the below-ground microbially driven mechanisms involved in plant invasion where other above-ground mechanisms have been exhausted. Microbes govern the world around us and interact with every living and non-living facet of the world. To reinforce the important underpinnings of the role of microorganisms in plant invasion, a systematic review of recently published articles was undertaken. Using the ScienceDirect database, five (5) search queries were used to generate 1221 research articles. After a two-step reduction was made based on relevance of the articles, a final total of 59 articles were retrieved. An additional 18 relevant articles were also assessed through the PubMed database for analysis to account for other invasive plants. Thirty-seven (37) invasive species were investigated where soil physiochemical and microbial community structure changes were most prevalent (32\% \& 39\% respectively) while enhanced mutualism, allelopathy and pathogen accumulation were reported less $(16 \%, 10 \% \& 3 \%$ respectively). In all invasive species assessed, the impact on plant invasion and inability of the native plants to compete was due to specific microbial associations of the invasive plant or disruption of the soil microbial community. This microbial community shift coincided with changes in physiochemical properties of the soil and the subsequent negative soil feedback for native plants. There is still an expanding potential for the use of biocontrol agents to aid restoration once the underpinnings of biotic resistance and enemy release are understood in a microbial and physiochemical context. The active and functional microbial community structure of the invasive plant rhizosphere and adjacent soil in its native and non-native region can offer a better inference of how they can be controlled
\end{abstract}


using novel-below ground biocontrol methods.

\section{Keywords}

Invasive Plant, Biotic Resistance, Biocontrol Agents, Enemy Release, Restoration

\section{Introduction}

The number of invasive plant species across the globe is astronomical. North America and Oceania have the highest prevalence of terrestrial invasive plant species (341) (Figure 1) with 1662 total invasive plants spread out across the major continents [1]. The high prevalence of invasive plants in higher income countries is mainly due to a constant up-tick in trade and transportation of goods as development progresses [2]. It is well known that exotic invasive plants contribute to disruption of economies, ecological structure and function of non-native regions in which they encroach [3]. Invasive plants have caused up to $40 \%$ of agricultural crop yield losses globally while displacing other native plant species [4]. Exotic invasive plants employ numerous classical mechanisms such as enemy-release, enhanced mutualism, novel weapons, allelopathy, pathogen accumulation to name a few [5] [6] [7] [8]. Most if not all these below-ground mechanisms of plant invasion have an effect on the soil microbial community, soil physiochemical and biogeochemical properties in the non-native invaded community [9] [10] [11] [12] [13]. All plants will indeed cause a disruption of the soil microbial community adjacent to its rhizosphere through plant exudate production influencing active recruitment and reduction of beneficial and antagonistic/pathogenic microorganisms respectively. Plants require essential nutrients from the soil such as $\mathrm{P}, \mathrm{N}, \mathrm{Ca}, \mathrm{Mg}, \mathrm{Fe}$ which may not be readily assimilated but available through recruitment of different microorganisms for which $\mathrm{C}$ exudates are produced by the plants in return. Many microorganisms in soil such as AMF/EMF, saprophytic and pathogenic fungi, $\mathrm{N}$-cycling bacteria, sulfate reducers [14] [15] [16] [17] and others with yet to be discerned mechanisms influence the soil nutrient, physiochemical and biogeochemical profile. If these changes are of benefit to the plant, a positive-soil feedback effect will result, enabling the proliferation of that plant or in the opposite scenario, development of a more negative-soil feedback reducing plant success. Invasive plants tend to be more resilient to abiotic and biotic changes than native plants. Due to the genetic differences between plants, the chemical make-up of their exudates would be unique to each plant creating their own novel rhizosphere microbial communities. The microbial component of native and non-native soils plays an important role in plant success and inevitably plant invasion [11] [18].

Many, if not all invasive plants, are not considered as a nuisance in their native habitat but once introduced to a new non-native environment, and consequently overcoming the establishment stage, they spread almost uncontrollably, 
damaging these naive ecosystems. The ease at which invasive plants overcome introduction and establishment is determined by abiotic and biotic factors in the non-native habitat [19]. This important determining factor of plant invasion is biotic resistance which is the reduction in invasive success by the native community through competition [19]. This factor is quite ubiquitous in North America and tropical/subtropical regions where environmental conditions are more favorable. Above-ground effects of biotic resistance are well seeded in literature [19] where high diversity of native plant species has mostly been effective in reducing establishment of invasive species. Poorly understood however, are the below-ground biotic factors [18]. It does however seem highly plausible that disruption of mycorrhizal and bacterial networks during disturbance, prolific exudate production by invasive plants, the lack of plant pathogens, herbivores and other insects in the non-native habitat contributes to lowered biotic resistance. The differences in soil microbial dynamics between the native and non-native habitat are also poorly understood when trying to understand invasion. To fully understand the role of microorganisms, this systematic review will focus on research articles where the prospective mechanism of plant invasion is delineated and the possible link between the mechanisms and members of the rhizosphere/adjacent soil under invasive plants which contribute to invasion are known. Studies employing next generation sequencing methods will be assessed in more detail since other older methods such as phospholipid fatty acid analysis (PFLA) give only a broad assessment of microbial community structure. This review will also investigate new strategies to assist with restoration of native populations and reduction of invasion.

\section{Main Objectives}

This systematic review article aims to assess globally, through the synthesis of 59+ research articles, the potential roles played by soil microorganisms during plant invasion. It also seeks to find the linkages between specific microbial associations in invasive plants or the shifts in microbial community structure and the inferred invasive mechanism. Lastly, it will identify potential solutions on the horizon for restoration of invaded sites through land management and soil microbiome engineering. We then determined the below specific objectives:

1) What is/are the most prevalent mechanism of plant invasion in tree and weedy species?

2) What roles do soil microorganisms play in relation to these different plant invasion mechanisms?

3) What land management and microbe engineering methods have been employed to reduce plant invasion or improve the success of native plants?

\section{Methods}

\subsection{Study Area}

In this review, terrestrial invasive plant species across six (6) continents were se- 
lected based on GISD descriptions and included: North America, South \& Central America, Oceania (Australia), Africa, Europe and Asia (Figure 1). Most Caribbean islands, Russia, Middle East and other temperate regions were excluded as there were minimal research articles on invasive plants that fulfilled the criteria for selection.

\subsection{Search Query}

To search for relevant journal articles, ScienceDirect database was used with 5 search queries seen below and selecting research articles only, dated from 2006-2021.

1) "Invasive plant" AND "microbiome" AND "rhizosphere";

2) "Exotic plant" AND "mycorrhiza" AND "invasive" AND "native";

3) "Invasive plant" AND "restoration" AND "soil" AND "bacteria" AND "fungi";

4) "Invasive weed" AND "rhizosphere" AND "sequencing";

5) "Invasive shrub" AND "microbe" AND "soil".

A total of 1221 review articles were found from using the search queries, which was further narrowed down to 139 after reading the title and deciding if the topic was relevant to the specific objectives. Another round of reductions was made after reviewing the abstract and conclusions and removal of duplicated articles to produce 59 research articles (Figure 2). In addition to the search query which missed a few important invasive plants, additional search queries were used on the NCBI PubMed database for more articles that fulfilled the objectives. These additional search queries shown below as examples provided an

\section{[Invasive Plant Distribution]}

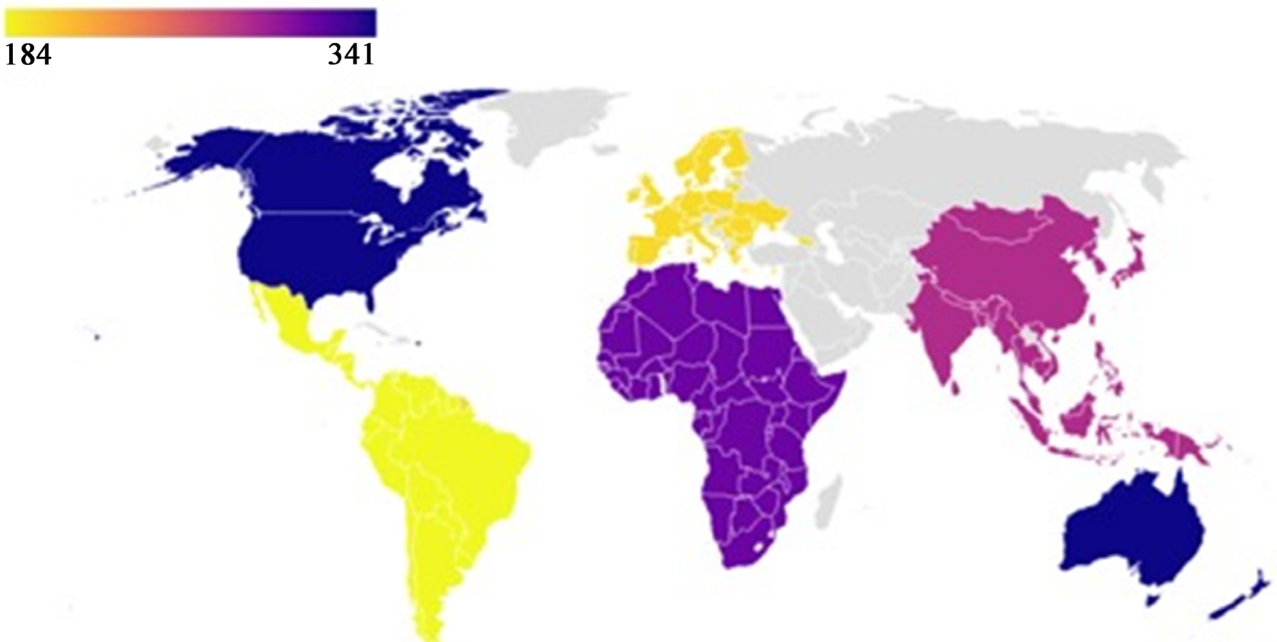

Data collected December 2,2021

Source:GSID·Created with Datawrapper

Figure 1. Current GISD (Global Invasive Species Distribution) of terrestrial invasive plant species across the different continents where North America and Australia exhibit the highest prevalence of plant invasion (341) and Central and South America having the lowest prevalence (184). 
- ScienceDirect database

- Initial Search Query total

- Relevance based on article title

Relevance based on fit to objectives

- Abstract review

Figure 2. Gradual reduction of research articles relevant to the objectives of the systematic review from the above mentioned 5 search queries in the ScienceDirect database.

additional 18 articles used to also obtain background information on invasive plant mechanisms and a more recent update on the global status quo of invasive plants control.

"Schinus terebinthifolius" "invasion" "soil microbes"

"Casuarina equisitifolia" "invasion" "soil microbes"

"Alliaria petiolata" "invasion" "allelopathy"

"invasive plant" "restoration strategies" "microbes"

\section{Results}

\subsection{Synthesis of Research Articles Based on Invasive Plant Mechanisms and Microbial Interactions}

A total of 37 terrestial invasive plants were used in this review and includes some of the most invasive plant species across the globe, including Alliaria petiolata (garlic mustard), Chromolaena odorata (siam weed), Solidago canadensis (Canada goldenrod), Ageratina adenophora (Crofton weed), Berberis thunbergii (Japanese barberry) and Schinus terebinthifolius (Brazilian pepper tree). Out of these 37 species, 21 had known microbial associations in the rhizosphere while for 16 others the rhizosphere microbial community structure or key taxonomic groups have not been fully deciphered. The effect of these 16 species which lacked known plant-microbial associations were still important as the authors showed the effect of the plants on the adjacent or bulk soil environment. From these 37 species of invasive plants, the projected invasive mechanisms were grouped into 4 categories (Figure 3). Some invasive plant species had multiple projected invasive mechanisms (Table 1). Competition was not added as a possible mechanism as it is certain that all invasive plant species through these different mechanisms improve their competitive advantage against native plant species through a positive soil feedback effect.

\subsection{Allelopathy \& Allelochemical Production}

A total of 7 of the 37 invasive plant species had reports of allelochemical production and/or allelopathic effects (3\%)-Figure 3. The mostly studied invasive plant exhibiting this mechanism include Alliaria petiolata, Impatiens glandulifera, Quercus rubra, Rosa rugrosa, Acacia dealbata, Schinus terebinthifolius and 
Table 1. List of select invasive plants across the world indicating their known/unknown microbial associations, invasive mechanisms along with their native and non-native regions.

\begin{tabular}{|c|c|c|c|c|c|}
\hline Invasive plant & Microbe association & Possible Mechanism & Native Region & $\begin{array}{l}\text { Non-Native } \\
\text { region }\end{array}$ & Reference \\
\hline $\begin{array}{l}\text { Acacia dealbata (silver } \\
\text { wattle) }\end{array}$ & Unknown & $\begin{array}{l}\text { allelochemical production-soil } \\
\text { bacteria community more affected }\end{array}$ & Australia & Portugal & {$[20]$} \\
\hline $\begin{array}{l}\text { Ageratina adenophora } \\
\text { (crofton weed) }\end{array}$ & $\begin{array}{l}\text { Clostridium }+ \\
\text { Enterobacter spp., } B . \\
\text { cereus }\end{array}$ & $\begin{array}{l}\text { Enhanced mutualism, increased } \\
\text { Nitrogen metabolism, increased litter } \\
\text { decomposition? }\end{array}$ & Mexico & China & $\begin{array}{l}{[21][22]} \\
{[23]}\end{array}$ \\
\hline $\begin{array}{l}\text { Alliaria petiolata (garlic } \\
\text { mustard) }\end{array}$ & Unknown & $\begin{array}{l}\text { allelopathy, higher } \mathrm{pH} \text {, higher } \mathrm{N} \text { rates- } \\
\text { affects resource availability, microbial } \\
\text { community shift, plant fungal } \\
\text { mutualism disruption (novel weapons) }\end{array}$ & Europe & $\begin{array}{l}\text { North } \\
\text { America }\end{array}$ & $\begin{array}{l}{[9][10]} \\
{[24][25]}\end{array}$ \\
\hline $\begin{array}{l}\text { Amaranthus retroflexus } \\
\text { (red-root amaranth) }\end{array}$ & N-fixing bacteria & $\begin{array}{l}\text { increases richness of } \mathrm{N} \text { fixing bacteria } \\
\text { to further success }\end{array}$ & South America & China & {$[26]$} \\
\hline $\begin{array}{l}\text { Amaranthus spinosus } \\
\text { (spiny amaranth) }\end{array}$ & $\mathrm{N}$-fixing bacteria & $\begin{array}{l}\text { changes soil nitrogen fixing bacteria } \\
\text { community structure }\end{array}$ & South America & China & [27] \\
\hline $\begin{array}{l}\text { Ambrosia artemisiifolia } \\
\text { L. (annual ragweed) }\end{array}$ & $\begin{array}{l}\text { sulfate reducing } \\
\text { bacteria, } \\
\text { Actinomycetes }\end{array}$ & $\begin{array}{l}\text { Disruption of abiotic and biotic soil } \\
\text { community, }<\mathrm{pH},>\text { soil organic } \\
\mathrm{C},>\mathrm{NPK}\end{array}$ & $\begin{array}{l}\text { Central } \\
\text { America }\end{array}$ & China & {$[28]$} \\
\hline $\begin{array}{l}\text { Berberis thunbergii DC. } \\
\text { (japanese barberry) }\end{array}$ & $\begin{array}{l}\text { Alphaproteobacteria } \\
\text { Nitrospirales \& } \\
\text { Pseudomonadaceae }\end{array}$ & increase in $\mathrm{N}$ cycling & Japan & USA & [29] \\
\hline $\begin{array}{l}\text { Brassica nigra (black } \\
\text { mustard) }\end{array}$ & Unknown & disrupts soil fungal mutualisms & North Africa & USA & {$[30]$} \\
\hline $\begin{array}{l}\text { Bromus tectorum } \\
\text { (cheatgrass) }\end{array}$ & Bacteriodetes & disruption of soil microbial community & Europe & USA & {$[3][31]$} \\
\hline $\begin{array}{l}\text { Carpobrotus edulis } \\
\text { (sour fig) }\end{array}$ & $\begin{array}{l}\text { Verrucomicrobia, } \\
\text { Acidobacteria, } \\
\text { Sphingomonadaceae }\end{array}$ & $\begin{array}{l}\text { soil physiochemical and microbial } \\
\text { community flux }\end{array}$ & South Africa & Spain & {$[32]$} \\
\hline $\begin{array}{l}\text { Casuarina equisitifolia } \\
\text { (Australian pine) }\end{array}$ & Frankia spp. & $\begin{array}{l}\text { soil nutrient flux, leaves have } \\
\text { allelopathic properties }\end{array}$ & Australia & USA & {$[33]$} \\
\hline $\begin{array}{l}\text { Centaurea solstitialis } \\
\text { (yellow starthistle) }\end{array}$ & $\begin{array}{l}\text { Proteobacteria, } \\
\text { Firmicutes, sulfate } \\
\text { reducing bacteria }\end{array}$ & $\begin{array}{l}\text { reduction in pathogen } \\
\text { accumulation/diversity }\end{array}$ & $\begin{array}{l}\text { Mediterranean } \\
\text { basin }\end{array}$ & USA & [11] [34] \\
\hline $\begin{array}{l}\text { Chromolaena odorata } \\
\text { (L.) (Siam weed) }\end{array}$ & $\begin{array}{l}\text { Fusarium } \\
\text { semitectum }\end{array}$ & $\begin{array}{l}\text { decrease in microbial biomass in } \\
\text { invaded soil, increase in organic } \mathrm{C}, \mathrm{N} \\
\text { and } \mathrm{P} \text {, soil pathogen accumulation }\end{array}$ & $\begin{array}{l}\text { North \& South } \\
\text { America }\end{array}$ & West Africa & [6] [35] \\
\hline $\begin{array}{l}\text { Conyza canadensis } \\
\text { (horseweed) }\end{array}$ & $\begin{array}{l}\text { Actinobacteria, } \\
\text { Sphingomonadaceae } \\
\text { Glomeromycota, }\end{array}$ & $\begin{array}{l}\text { self-promoting soil nutrient flux, } \\
\text { microbial community structure } \\
\text { shift-decreased fungal diversity }\end{array}$ & $\begin{array}{l}\text { North \& South } \\
\text { America }\end{array}$ & China & {$[36]$} \\
\hline $\begin{array}{l}\text { Falcataria moluccana } \\
\text { (Moluccan albizia) }\end{array}$ & Unknown & $\begin{array}{l}\text { shift in microbial and biogeochemical } \\
\text { community structure-decreased } \mathrm{P} \text {, } \\
\text { increased } \mathrm{C} \text { and } \mathrm{N}\end{array}$ & South Asia & USA & {$[37]$} \\
\hline
\end{tabular}




\section{Continued}

\begin{tabular}{|c|c|c|c|c|c|}
\hline $\begin{array}{l}\text { Flaveria bidentis } \\
\text { (coastal plain yellowtop) }\end{array}$ & $\begin{array}{l}\text { Rhizophagus } \\
\text { intraradices }\end{array}$ & $\begin{array}{l}\text { Enhanced competition/mutualism } \\
\text { through AMF colonization }\end{array}$ & South America & China & {$[38]$} \\
\hline $\begin{array}{l}\text { Heracleum } \\
\text { mantegazzianum (giant } \\
\text { hogweed) }\end{array}$ & Unknown & $\begin{array}{l}\text { Changes in soil chemical and biological } \\
\text { characteristics }\end{array}$ & Central Asia & $\begin{array}{l}\text { Czech } \\
\text { Republic }\end{array}$ & [39] \\
\hline $\begin{array}{l}\text { Impatiens glandulifera } \\
\text { (Himalayan balsam) }\end{array}$ & Unknown & $\begin{array}{l}\text { allelochemical production } \\
\text { (naphthoquinone)_-disrupts ECM \& AMF } \\
\text { interactions with native plants, disrupts } \\
\text { hyphal associations-increase in } \\
\text { saprophytic fungi }\end{array}$ & Himalayas & Switzerland & {$[40][41]$} \\
\hline $\begin{array}{l}\text { Kalanchoe } \\
\text { daigremontiana } \\
\text { (alligator plant) }\end{array}$ & Unknown & increases $\mathrm{C}$ and $\mathrm{N}$ mineralization & Madagascar & Venezuela & {$[42]$} \\
\hline $\begin{array}{l}\text { Lantana camara (West } \\
\text { Indian lantana) }\end{array}$ & Unknown & increased nutrient cycling-C, $N \& P$ & $\begin{array}{l}\text { North \& South } \\
\text { America }\end{array}$ & India & {$[43]$} \\
\hline $\begin{array}{l}\text { Melinis minutiflora } \\
\text { (molasses grass) }\end{array}$ & Nitrifying bacteria & increase in $\mathrm{N}$ cycling & Africa & Brazil & {$[44]$} \\
\hline $\begin{array}{l}\text { Mikania micrantha } \\
\text { (bitter vine) }\end{array}$ & $\begin{array}{l}\text { P solubilizing } \\
\text { bacteria-Burkholde } \\
\text { ria spp. }\end{array}$ & $\begin{array}{l}\text { increased } \mathrm{P} \text { in plant-enhanced } \\
\text { mutualism, increased } \mathrm{C} \text { accumulation and } \\
\text { release to soil microbes }\end{array}$ & $\begin{array}{l}\text { Central \& } \\
\text { South America }\end{array}$ & China & [45] [46] \\
\hline $\begin{array}{l}\text { Phragmites australis } \\
\text { (common reed) }\end{array}$ & Unknown & $\begin{array}{l}\text { increased nutrient availability in } \\
\text { rhizosphere-positive plant feedback }\end{array}$ & $\begin{array}{l}\text { Eastern } \\
\text { Australia }\end{array}$ & Australia & {$[12]$} \\
\hline $\begin{array}{l}\text { Polygonum cuspidatum } \\
\text { (Japanese knotweed) }\end{array}$ & Unknown & $\begin{array}{l}\text { increased SOC, } \mathrm{N} \text { deposition enhanced } \\
\text { SOC accumulation }\end{array}$ & East Asia & USA & {$[47]$} \\
\hline $\begin{array}{l}\text { Pseudotsuga menziesii } \\
\text { (douglas fir) }\end{array}$ & AMF Association & $\begin{array}{l}\text { Enhanced mutualism effect, alters } \\
\text { mycorrhizal community structure }\end{array}$ & $\begin{array}{l}\text { North } \\
\text { America }\end{array}$ & Argentina & [48] [49] \\
\hline $\begin{array}{l}\text { Quercus rubra (native } \\
\text { red oak) }\end{array}$ & Unknown & $\begin{array}{l}\text { allelochemical production (phenols) } \\
\text { elicits microbial community structure } \\
\text { shift, shift in soil physiochemical } \\
\text { properties }\end{array}$ & $\begin{array}{l}\text { North } \\
\text { America }\end{array}$ & Poland & [13] [50] \\
\hline $\begin{array}{l}\text { Reynoutria japonica } \\
\text { (Japanese knotweed) }\end{array}$ & Unknown & $\begin{array}{l}\text { reduces AMF species richness and } \\
\text { abundance }\end{array}$ & East Asia & Poland & {$[51]$} \\
\hline $\begin{array}{l}\text { Robinia pseudoacacia } \\
\text { (black locust) }\end{array}$ & Unknown & $\begin{array}{l}\text { shift in microbial community } \\
\text { structure-increased nitrification and } \\
\text { acidification, reduced biodiversity }\end{array}$ & USA & Italy & {$[52]$} \\
\hline $\begin{array}{l}\text { Rosa rugosa (beach } \\
\text { rose) }\end{array}$ & AMF association & $\begin{array}{l}\text { soil nutrient flux, >total N, C \& P, } \\
\text { decrease in Microbial biomass, high } \\
\text { phenolic content (allelochemical) }\end{array}$ & Asia & Poland & {$[53]$} \\
\hline $\begin{array}{l}\text { Schinus terebinthifolius } \\
\text { (brazilian pepper tree) }\end{array}$ & $\begin{array}{l}\text { Glomus spp., } \\
\text { Verrucomicrobia, } \\
\text { Acidobacteria }\end{array}$ & $\begin{array}{l}\text { shift in soil microbial community- } \\
\text { decreased prevalence of soil fungal } \\
\text { pathogens, allelopathy, competition }\end{array}$ & South America & USA & $\begin{array}{l}{[16][54]} \\
{[55][56]}\end{array}$ \\
\hline $\begin{array}{l}\text { Solidago canadensis } \\
\text { (Canada goldenrod) }\end{array}$ & $\begin{array}{l}\text { Nitrogen fixing } \\
\text { bacteria, Glomus } \\
\text { geosporum }\end{array}$ & $\begin{array}{l}\text { increase soil } \mathrm{N} \text { availability (enhanced } \\
\text { mutualism hypothesis), reduction of } G \text {. } \\
\text { mosseae prevalence required by natives }\end{array}$ & $\begin{array}{l}\text { North } \\
\text { America }\end{array}$ & China & $\begin{array}{l}{[15][57]} \\
{[58]}\end{array}$ \\
\hline
\end{tabular}




\section{Continued}

\begin{tabular}{|c|c|c|c|c|c|}
\hline $\begin{array}{l}\text { Solidago gigantea (giant } \\
\text { goldenrod) }\end{array}$ & $\begin{array}{l}\text { Phosphate } \\
\text { solubilizing bacteria }\end{array}$ & increased phosphorus mineralization & $\begin{array}{l}\text { North } \\
\text { America }\end{array}$ & China & {$[14]$} \\
\hline $\begin{array}{l}\text { Sorghum halepense } \\
\text { (johnson grass) }\end{array}$ & $\begin{array}{l}\text { Nitrogen fixing } \\
\text { bacteria, } \\
\text { Pseudomonas sp., } \\
\text { Caulobacter sp., } \\
\text { Sphingobium sp., } \\
\text { Agrobacterium } \\
\text { tumefaciens }\end{array}$ & $\begin{array}{l}\text { alteration of biogeochemical cycles }-\mathrm{N} \text {, } \\
\mathrm{C}, \mathrm{P}, \mathrm{Fe}, \mathrm{IAA} \text { production }\end{array}$ & $\begin{array}{l}\text { Asia/Northern } \\
\text { Africa }\end{array}$ & USA & [17] \\
\hline $\begin{array}{l}\text { Spartina alterniflora } \\
\text { (smooth cordgrass) }\end{array}$ & Unknown & $\begin{array}{l}\text { microbial metabolism flux driven by } \mathrm{pH} \\
\text { and salinity, AMF colonization disruption }\end{array}$ & $\begin{array}{l}\text { North } \\
\text { America }\end{array}$ & China & [59] [60] \\
\hline $\begin{array}{l}\text { Thymus vulgaris } \mathrm{L} \text {. } \\
\text { (common thyme) }\end{array}$ & Unknown & $\begin{array}{l}\text { shifts in soil physiochemical } \\
\text { properties-decreased soil } \mathrm{P} \text {, moisture }\end{array}$ & $\begin{array}{l}\text { Southern } \\
\text { Europe }\end{array}$ & $\begin{array}{l}\text { New } \\
\text { Zealand }\end{array}$ & {$[61]$} \\
\hline $\begin{array}{l}\text { Wedelia trilobata } \\
\text { (trailing daisy) }\end{array}$ & Unknown & $\begin{array}{l}\text { shift in soil biogeochemical properties, } \\
\text { nitrogen cycling- } \mathrm{pH}, \mathrm{Ca} \text {, increase } \\
\text { richness of fungal community }\end{array}$ & $\begin{array}{l}\text { Central } \\
\text { America }\end{array}$ & China & {$[62]$} \\
\hline
\end{tabular}

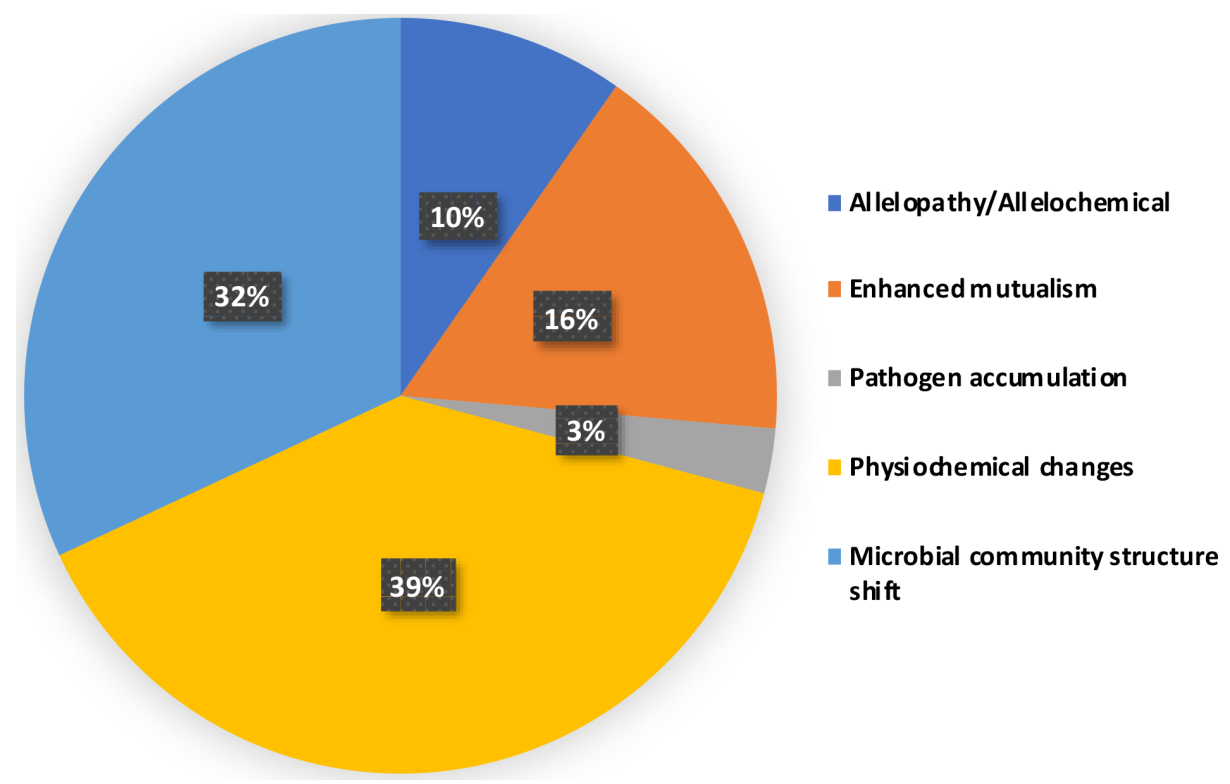

Figure 3. Distribution of plant invasion mechanism across the 37 species of invasive plants undertaken in this study.

Casuarina equisitifolia. The most widely studied model invasive plant for allelopathy is Alliaria petiolata where specific glucosinolates were isolated and found to be directly inhibitory to adjacent native plant species [10] [24]. Since this chemical is very unique, a novel weapons mechanism is also mentioned where the non-native habitat environment has no evolutionary history with this chemical. Impatiens glandulifera also produces a known allelochemical naphthoquinone which caused a disruption in fungal interactions with native plants [40] [41]. Schinus and Casuarina also exhibited similar effects but more so showing direct allelopathy of plant extract and leaf litter in inhibiting germination and 
succession of native plants [33] [56]. For all these plants, allelopathy/allelechemical production did not operate solely on its own but occurred in combination with other invasive mechanisms where there was a direct correlation between production and changes in the soil microbiome community and physiochemical characteristics of the soil.

\subsection{Enhanced Mutualism}

Enhanced mutualism of invasive plants was reported in 12 of the 37 species (16\%). This mechanism could only be confirmed fully for plants where an investigation of specific taxa and their functional properties were assessed under the rhizosphere of the invasive plant. The most widely studied examples include Ageratina adenophora which was enriched with Clostridium, Enterobacter and Bacillus cereus which directly impacted its growth and competition against surrounding native plants [21] [22] [23]. Berberis thunbergii showed an increase in nitrifying bacteria and associated functional properties which shifted the microbial community structure adjacent to the plant [29]. Quite a few plants that exhibited enhanced mutualisms accomplished this by forming strong associations with arbuscular mycorrhizal fungi, Frankia spp. and phosphate solubilizing bacteria as seen for invasive plants such as $S$. terebinthifolius, Conyza canadensis, Flaveria bidentis and Mikania micrantha [16] [36] [38] [45] [46]

\subsection{Pathogen Accumulation}

Only two invasive species reported a significant impact of pathogen accumulation in the adjacent soil of the plants during invasion. These two species were Chromoloena odorata and to a lesser extent Impatiens glandulifera. C. odorata with its association with known fungal pathogen Fusarium semitectum increased over 2-fold the concentration of fungal spores in adjacent soil during invasion [6]. This led to a decrease in overall microbial mass and increases in soil nutrient level [35]. The rhizosphere microbial associations of Impatiens glandulifera are mostly unknown but it was shown to increase the prevalence of saprophytic and potentially pathogenic fungi during invasion [41].

\subsection{Changes in Physiochemical Properties of Soil}

This mechanism was the most widely reported, exhibited by 28 invasive plants (39\%). Soil physiochemical changes go in tandem with microbial community structure shifts, allelochemical production and pathogen accumulation in over $70 \%$ of plants. It was seen mainly with plants such as Casuarina, Berberis, Amaranthus sp. and Quercus that harbored nitrogen fixing bacteria or had allelochemical production as an additional mechanism.

\subsection{Soil Microbial Community Structure Shift}

This was the second most prevalent mechanism (32\%) exhibited by the invasive plant species. The impacts of soil microbial community shifts coincided with 
shifts in physiochemical properties of the soil, which was reported in plants such as Sorghum halepense, Solidago canadensis, Rosa rugosa and Quercus rubra. Both allelochemical/allelopathy and pathogen accumulation mechanisms described above involved microbial community structure shifts. Notably, it was shown that a shift in microbial community structure after increased invasion of horseweed which accumulated Actinobacteria, Sphingomonadaceae and mycorrhiza in its rhizosphere caused a soil nutrient flux [36]. These associations affected negative soil feedback for native plants while having positive-soil feedback for the invasive. In a similar pattern, Rodríguez-Caballero et al., 2020 [32] showed that the invasive plant Carpobrotus edulis affects microbial community structure and soil physiochemical properties leading to negative soil feedback for native and positive soil feedback for the invasive.

\subsection{Restoration Strategies Employed to Reduce Plant Invasions}

Land managers continue to employ mainly above-ground methods of prescribed burning and herbicide treatments to control the spread of invasive plants. With the known significance and importance of the soil microbial community to invasion what has been shown in the literature to be effective based on the geographical and invasive plant context? Prescribed burning for one, even though it mainly affects the above ground biota, also can affect the below ground microbial community in a significant way. Burning creates a somewhat "sterile" environment with reduced activity of mycorrhiza, bacteria and lowered nutrient levels. It was shown that one native plant was able to out-compete an invasive plant in the burnt (sterilized) soil [63]. In another indirect way, the use of a parasitic climbing plant Cuscata australis shifted the rhizosphere microbial community under the invasive plant Alternanthera philoxeroides improving the success of nearby native plants [64]. This novel method is one of the first employing the use of natural enemy parasitic plants in controlling invasive plants.

Invasive plants through the disruption of the soil microbial community which in turn affects the biogeochemical and physiochemical properties of the soil can have long term effects, even after their removal. This legacy effect [55] can be restored by the use of microbial inoculants [65]. This microbial inoculant which includes beneficial bacteria, mycorrhiza and other fungi was shown to improve native seedling performance in the presence of invasive plants. Another unique study employed the use of weed-suppressive bacteria (Pseudomonas fluorescens) to reduce the invasive effect of downy brome (Bromus tectorum L.), jointed goatgrass (Aegilops cylindrica L.) and medusa head (Taeniatherum caput-medusae L.) [66]. One of the most compelling findings involved the transfer of pathogens from the native plant region to the non-native region where the same plant is now invasive. This was reported for Euphorbia spp. (leafy spurge) where the most virulent pathogens associated with the native plant (Fusarium + Rhizoctonia sp.) where isolated and used as biocontrol agents to stem invasion in the non-native range [67]. 
There is some caution however to the use of microbial inoculants, as due to the specificity of interactions some of these microorganisms with plants, they may not have the same effect in different geographical locations and soil with varied nutrient levels and physiochemical properties. In one study, it was shown that inoculation of plant growth promoting bacteria influenced the proliferation of invasive A. adenophora over other native plants [68]. [69] Dai et al., 2016 also reported that addition of PGP endophytic bacteria such as Bacillus sp. improved the growth of the invasive plant Wedelia trilobata over the native congener.

\section{Discussion}

Biotic resistance of soil is the key element in the determination of a plant becoming invasive [19]. If there is a significant difference in the soil biota and abiotic factors in the native vs non-native region this will more than likely cause a reduction in biotic resistance and consequently establishment and spread of the newly invasive plant. These reports [21] [67] gave some credence to the importance of the enemy release hypothesis for invasive plants. Enemy release and biotic resistance in a soil microbial community context have the greatest potential for understanding why plants native in one geographic location become invasive in another location. [67] showed that the soil pathogens which have been evolutionarily adapted to the plant in the native region are missing or of low prevalence in the non-native region where the plant becomes invasive. But by transferring the native soil pathogens to the non-native region, there was a reduction in the succession of the invasive plant. Similarly, the use of pathogens and other non-mycorrhizal microorganisms from native congeners which have the ability to reduce plant invasion or increase biotic resistance in the non-native range was shown for invasive plants $M$. micrantha and $E$. catarium [21]. The lack of a highly diverse soil pathogen community negatively affects the ability of the non-native ecosystem to reduce the establishment of the invasive plant, which is tied into a low biotic resistance effect. Both these mechanisms are influenced by the soil microbial community.

The impact of the soil microbial community during plant invasion is normally at the center of all the different invasive mechanisms. It is still difficult however to determine if the changes in microbial communities are driven by direct plant microbial interactions or as a result of plant-driven changes in soil properties [70]. This is compounded by the fact that the pathogen accumulation effect for C. odorata was eliminated by sterile soil treatments and application of activated carbon removing the microbial and possible physiochemical effects of its invasion [6] [10]. Two research authors [10] [71] showed that soil biota might be involved in the deactivation of allelochemicals released by the invasive A. petiolata and Eupatorium adenophorum respectively. Another factor indirectly influencing allelochemicals fate in soil can be related to the quality and quantity of soil organic matter which usually increases during invasion.

In two studies supporting the importance of soil microbes, Flaveria bidentis 
and Pseudotsuga menziesii invasion through enhanced mutualism with AMF species led to a subsequent shift in the soil microbial community structure and negative soil feedback for adjacent native plants [38] [48]. A similar effect was observed for the invasive plant $R$. rugosa, which formed specific AMF associations while producing allelochemicals in the soil, constructed its own niche environment to improve its positive soil feedback at the detriment of native plants [53]. The effect of invasive plants on important native mycorrhiza community structure was evident in reports involving $S$. terebinthifolius and $S$. canadensis [15] [16]. More so for $S$. canadensis there was a direct link between the increase in composition of one Glomus species and depletion of another that lead to positive feedback for the invasive plant and a more negative feedback for the native plant. These microbial associations with invasive plants either directly or indirectly promote positive soil feedback loops and increased competition and dominance in relation to native plant species.

Two studies, however, had limited support for the role of microorganisms in plant invasion. One reported no significant change in microbial and eukaryotic communities in the invaded and native range for Solidago spp. [72]. Their taxonomic analyses were limited as they didn't fully tease apart the different taxonomic levels and reported mainly at the phylum and class level where significant changes may not be seen. For the invasive Acacia spp. soil fungal communities were similar in the invaded and native range and showed no effect on the success or failure of the invasive plant [73]. Again, a thorough analysis of the rhizosphere of the plants in both regions was not undertaken and the authors reported a major limitation in the type of primer used which may have detected a low diversity of species.

Invasive plants invest more resources in biomass allocation than defensive allocation in the non-native range, making them more competitive than native species. In their native habitat, there is a balancing act in allocating resources for defense from pathogens and recruitment of beneficial microbes. This balancing act causes a negative to neutral and possibly slightly positive soil feedback of plants in native habitat. There is also a longer evolutionary history of the native plants and soil pathogens where there is a constant ecological pressure that resists their proliferation and spread from becoming invasive. In controlling invasive plants, it is essential that a thorough analysis of the microbial community structure of the invaded and native region is undertaken using next generation sequencing methods, not only to know which taxa are present but those who play an active and functional role. If the microbial elements involved in enemy release and biotic resistance are fully understood, new biocontrol agents can be employed as an adjacent strategy for the eradication of invasive plants and restoration of invaded areas.

\section{Authors' Contributions}

KD put together the manuscript along with the analysis of the different journal 
articles. JM and OS helped with sourcing the different articles and review. NE also helped with the final review of the article.

\section{Acknowledgements}

The authors would like to thank Florida Atlantic University and the John Nambu Scholarship award committee for their support.

\section{Conflicts of Interest}

The authors declare no conflicts of interest regarding the publication of this paper.

\section{References}

[1] Global Invasive Species Database (2021). http://www.iucngisd.org/gisd/search.php

[2] Seebens, H. (2018) Global Rise in Emerging Alien Species Results From Increased Accessibility of New Source Pools. Proceedings of the National Academy of Sciences of the United States of America, 115, E2264-E2273. https://doi.org/10.1073/pnas.1719429115

[3] Gibbons, S.M., Lekberg, Y., Mummey, D.L., Sangwan, N., Ramsey, P.W. and Gilbert, J.A. (2017) Invasive Plants Rapidly Reshape Soil Properties in a Grassland Ecosystem. mSystems, 2, Article ID: e00178-16. https://doi.org/10.1128/msystems.00178-16

[4] Fried G., Chauvel B., Reynaud P. and Sache I. (2017) Decreases in Crop Production by Non-native Weeds, Pests, and Pathogens. In: Vilà M. and Hulme P., Eds., Impact of Biological Invasions on Ecosystem Services, Vol. 12, Springer, Cham, 83-101. https://doi.org/10.1007/978-3-319-45121-3_6

[5] Keane R. and Crawley M. (2002) Exotic Plant Invasions and the Enemy Release Hypothesis. Trends in Ecology Evolution, 17, 164-170. https://doi.org/10.1016/S0169-5347(02)02499-0

[6] Mangla, S. and Callaway, R.M. (2008) Exotic Invasive Plant Accumulates Native Soil Pathogens Which Inhibit Native Plants. Journal of Ecology, 96, 58-67. https://doi.org/10.1111/j.1365-2745.2007.01312.x

[7] Callaway, R.M., Thelen, G.C., Rodriguez, A. and Holben, W.E. (2004) Soil Biota and Exotic Plant Invasion. Nature, 427, 731-733. https://doi.org/10.1038/nature02322

[8] Reinhart, K.O. and Callaway, R.M. (2006) Soil Biota and Invasive Plants. New Phytologist, 170, 445-457. https://doi.org/10.1111/j.1469-8137.2006.01715.x

[9] Callaway, R.M., Cipollini, D., Barto, K., Thelen, G.C., Hallett, S.G., Prati, D., Stinson, K. and Klironomos, J. (2008) Novel Weapons: Invasive Plant Suppresses Fungal Mutualists in America but Not in its Native Europe. Ecology, 89, 1043-1055. https://doi.org/10.1890/07-0370.1

[10] Lankau, R. (2010) Soil Microbial Communities Alter Allelopathic Competition between Alliaria petiolata and a Native Species. Biological Invasions, 12, 2059-2068. https://doi.org/10.1007/s10530-009-9608-z

[11] Batten, K.M., Scow, K.M., Davies, K.F. and Harrison, S.P. (2006) Two Invasive Plants Alter Soil Microbial Community Composition in Serpentine Grasslands. Biological Invasions, 8, 217-230. https://doi.org/10.1007/s10530-004-3856-8

[12] Uddin, M.N. and Robinson, R.W. (2018) Can Nutrient Enrichment Influence the 
Invasion of Phragmites australis? Science of the Total Environment, 613-614, 1449-1459. https://doi.org/10.1016/j.scitotenv.2017.06.131

[13] Stanek, M., Zubek, S. and Stefanowicz, A.M. (2021) Differences in Phenolics Produced by Invasive Quercus Rubra and Native Plant Communities Induced Changes in Soil Microbial Properties and Enzymatic Activity. Forest Ecology and Management, 482, Article ID: 118901. https://doi.org/10.1016/j.foreco.2020.118901

[14] Chapuis-Lardy, L., Vanderhoeven, S., Dassonville, N., Koutika, L. and Meerts, P. (2006) Effects of the Invasive Plant Solidago gigantea on Soil Phosphorus. Biology and Fertility of Soils, 42, 481-489. https://doi.org/10.1007/s00374-005-0039-4

[15] Zhang, Q., Yang, R., Tang, J., Yang, H., Hu, S. and Chen, X. (2010) Positive Feedback between Mycorrhizal Fungi and Plants Influences Plant Invasion Success and Resistance to Invasion. PLoS ONE, 5, Article ID: e12380.

https://doi.org/10.1371/journal.pone.0012380

[16] Dawkins, K. and Esiobu, N. (2017) Arbuscular and Ectomycorrhizal Fungi Associated with the Invasive Brazilian Pepper Tree (Schinus terebinthifolius) and Two Native Plants in South Florida. Frontiers in Microbiology, 8, Article No. 665.

https://doi.org/10.3389/fmicb.2017.00665

[17] Rout, M.E., Chrzanowski, T.H., Smith, W.K. and Gough, L. (2013) Ecological Impacts of the Invasive Grass Sorghum halepense on Native Tallgrass Prairie. Biological Invasions, 15, 327-339. https://doi.org/10.1007/s10530-012-0289-7

[18] Dawkins K. and Esiobu N. (2016) Emerging Insights on Brazilian Pepper Tree (Schinus terebinthifolius) Invasion: The Potential Role of Soil Microorganisms. Frontiers in Plant Science, 7, Article No. 712.

https://doi.org/10.3389/fpls.2016.00712

[19] Levine, J.M., Adler, P.B. and Yelenik, S.G. (2004) A Meta-Analysis of Biotic Resistance to Exotic Plant Invasions. Ecology Letters, 7, 975-989. https://doi.org/10.1111/j.1461-0248.2004.00657.x

[20] Lorenzo, P., Pereira, C.S. and Rodríguez-Echeverría, S. (2013) Differential Impact on Soil Microbes of Allelopathic Compounds Released by the Invasive Acacia dealbata Link. Soil Biology and Biochemistry, 57, 156-163.

https://doi.org/10.1016/j.soilbio.2012.08.018

[21] Chen, L., Fang, F., Zhou, J., Yang, Z., Dong, X., Dai, G. and Zhang, H. (2019) Enrichment of Soil Rare Bacteria in Root by an Invasive Plant Ageratina adenophora. Science of the Total Environment, 683, 202-209.

https://doi.org/10.1016/j.scitotenv.2019.05.220

[22] Zhao, M., Lu, X., Zhao, H., Yang, Y., Hale, L., Gao, Q., Liu, W., et al. (2019) Ageratina adenophora Invasions are Associated with Microbially Mediated Differences in Biogeochemical Cycles. Science of the Total Environment, 677, 47-56.

https://doi.org/10.1016/j.scitotenv.2019.04.330

[23] Sun, Y., Zhang, Q., Zhao, Y., Diao, Y., Gui, F. and Yang G. (2021) Beneficial Rhizobacterium Provides Positive Plant-Soil Feedback Effects to Ageratina adenophora. Journal of Integrative Agriculture, 20, 1327-1335. https://doi.org/10.1016/S2095-3119(20)63234-8

[24] Morris, S.J., Herrmann, D.L., McClain, J., Anderson, J. and McConnaughay, K.D. (2012) The Impact Of Garlic Mustard on Sandy Forest Soils. Applied Soil Ecology, 60, 23-28. https://doi.org/10.1016/j.apsoil.2012.02.005

[25] Stinson, K.A., Campbell, S.A., Powell, J.R., Wolfe, B.E., Callaway, R.M., Thelen, G.C., et al. (2006) Invasive Plant Suppresses the Growth of Native Tree Seedlings by Disrupting Belowground Mutualisms. PLoS Biology, 4, Article No. e140. 
https://doi.org/10.1371/journal.pbio.1001817

[26] Wang, C., Zhou, J., Liu, J. and Jiang, K. (2017) Differences in Functional Traits between Invasive and Native Amaranthus Species under Different Forms of N Deposition. The Science of Nature, 104, Article No. 59.

https://doi.org/10.1007/s00114-017-1482-4

[27] Cheng, H., Wang, S., Wei, M., Yu, Y. and Wang, C. (2021) Alien Invasive Plant Amaranthus spinosus Mainly Altered The Community Structure Instead of The A Diversity of Soil N-Fixing Bacteria Under Drought. Acta Oecologica, 113, Article ID: 103788. https://doi.org/10.1016/j.actao.2021.103788

[28] Li, H., Xiao, B., Liu, W. and Wan, F. (2014) Changes in Soil Biota Resulting from Growth of the Invasive Weed, Ambrosia artemisiifolia L. (Compositae), Enhance its Success and Reduce Growth of Co-Occurring Plants. Journal of Integrative Agriculture, 13, 1962-1971. https://doi.org/10.1016/S2095-3119(13)60569-9

[29] Coats, V.C., Pelletreau, K.N. and Rumpho, M.E. (2014) Amplicon Pyrosequencing Reveals the Soil Microbial Diversity Associated with Invasive Japanese Barberry (Berberis thunbergii DC.). Molecular Ecology, 23, 1318-1332. https://doi.org/10.1111/mec.12544

[30] Pakpour, S. and Klironomos, J. (2015) The Invasive Plant, Brassica nigra, Degrades Local Mycorrhizas across a Wide Geographical Landscape. Royal Society Open Science, 2, Article ID: 150300. https://doi.org/10.1098/rsos.150300

[31] Weber, C.F., King, G.M. and Aho, K. (2015) Relative Abundance of and Composition within Fungal Orders Differ between Cheatgrass (Bromus tectorum) and Sagebrush (Artemisia tridentata)-Associated Soils. PLoS ONE, 10, Article ID: e0117026. https://doi.org/10.1371/journal.pone.0117026

[32] Rodríguez-Caballero, G., Caravaca, F., Díaz, G., Torres, P. and Roldán, A. (2020) The Invader Carpobrotus edulis Promotes a Specific Rhizosphere Microbiome across Globally Distributed Coastal Ecosystems. Science of the Total Environment, 719, Article ID: 137347. https://doi.org/10.1016/j.scitotenv.2020.137347

[33] Pernas, T., Wheeler, G., Langeland, K., Golden, E., Purcell, M., Taylor, J., et al. (2013) Australian Pine Management Plan for Florida. Florida Exotic Pest Plant Council. http://www.fleppc.org

[34] Lu-Irving, P., Harencár, J.G., Sounart, H., Welles, S.R., Swope, S.M., Baltrus, D.A. and Dlugosch, K.M. (2019) Native and Invading Yellow Starthistle (Centaurea solstitialis) Microbiomes Differ in Composition and Diversity of Bacteria. mSphere, 4, Article ID: e00088-19. https://doi.org/10.1128/mSphere.00088-19

[35] Koné, A.W., Kassi, S.A.Y., Koffi, B.Y., Masse, D., Maïga, A.A., Tondoh, J.E., et al. (2021) Chromolaena odorata (L.) K\&R (Asteraceae) Invasion Effects on Soil Microbial Biomass and Activities in a Forest-Savanna Mosaic. CATENA, 207, Article ID: 105619. https://doi.org/10.1016/j.catena.2021.105619

[36] Zhang, H., Goncalves, P., Copeland, E., Qi, S., Dai, Z., Li, G., et al. (2020) Invasion by the Weed Conyza canadensis Alters Soil Nutrient Supply and Shifts Microbiota Structure. Soil Biology and Biochemistry, 143, Article ID: 107739.

https://doi.org/10.1016/j.soilbio.2020.107739

[37] Allison, S.A., Nielsen, C. and Hughes, R.F. (2006) Elevated Enzyme Activities in Soils Under the Invasive Nitrogen-Fixing Tree Falcataria moluccana. Soil Biology and Biochemistry, 38, 1537-1544. https://doi.org/10.1016/j.soilbio.2005.11.008

[38] Zhang, F., Li, Q., Chen, F., Xu, H., Inderjit and Wan, F. (2017) Arbuscular Mycorrhizal Fungi Facilitate Growth and Competitive Ability of an Exotic Species Flaveria bidentis. Soil Biology and Biochemistry, 115, 275-284. 
https://doi.org/10.1016/j.soilbio.2017.08.019

[39] Jandová, K., Klinerová, T., Müllerová, J., Pyšek, P., Pergl, J., Cajthaml, T. and Dostál, P. (2014) Long-Term Impact of Heracleum mantegazzianum Invasion on Soil Chemical and Biological Characteristics. Soil Biology and Biochemistry, 68, 270-278. https://doi.org/10.1016/j.soilbio.2013.10.014

[40] Ruckli, R., Rusterholz, H. and Baur. B. (2016) Disrupting Ectomycorrhizal Symbiosis: Indirect Effects of an Annual Invasive Plant on Growth and Survival of Beech (Fagus sylvatica) Saplings. Perspectives in Plant Ecology, Evolution and Systematics, 19, 12-20. https://doi.org/10.1016/j.ppees.2016.01.005

[41] Gaggini, L., Rusterholz, H. and Baur. B. (2019) The Annual Invasive Plant Impatiens glandulifera Reduces Hyphal Biomass of Soil Fungi in Deciduous Forests. Fungal Ecology, 39, 242-249. https://doi.org/10.1016/j.funeco.2018.12.004

[42] Herrera, I., Ferrer-Paris, J.R., Benzo, D., Flores, S., Garcia, B. and Nassar, J.M. (2018) An Invasive Succulent Plant (Kalanchoe daigremontiana) Influences Soil Carbon and Nitrogen Mineralization in a Neotropical Semiarid Zone. Pedosphere, 28, 632-643. https://doi.org/10.1016/S1002-0160(18)60029-3

[43] Kumar, M., Kumar, S.,Verma, A.K., Joshi, R.K. and Garkoti, S.C. (2021) Invasion of Lantana camara and Ageratina adenophora Alters The Soil Physico-Chemical Characteristics and Microbial Biomass of Chir Pine Forests in The Central Himalaya, India. CATENA, 207, Article ID: 105624.

https://doi.org/10.1016/j.catena.2021.105624

[44] Ribeiro, P.C.D., Menendez, E., da Silva, D.L., Bonieck, D., Ramírez-Bahena, M.H., Resende-Stoianoff, M.A., et al. (2017) Invasion of the Brazilian campo rupestre by the Exotic Grass Melinis minutiflora is Driven by the High Soil N Availability and Changes in the N Cycle. Science of the Total Environment, 577, 202-211. https://doi.org/10.1016/j.scitotenv.2016.10.162

[45] Sun, F., Ou, Q., Wang, N., Guo, Z., Ou, Y., Li, N. and Peng, C. (2020) Isolation and Identification of Potassium-Solubilizing Bacteria from Mikania micrantha Rhizospheric Soil and Their Effect on M. micrantha Plants. Global Ecology and Conservation, 23, Article ID: e01141. https://doi.org/10.1016/j.gecco.2020.e01141

[46] Ni, G., Zhao, P., Huang, Q., Zhu, L., Hou, Y., Yu, Y., Ye, Y. and Ouyang, L. (2020) Mikania micrantha Invasion Enhances the Carbon (C) Transfer from Plant to Soil and Mediates the Soil C Utilization through Altering Microbial Community. Science of the Total Environment, 711, Article ID: 135020.

https://doi.org/10.1016/j.scitotenv.2019.135020

[47] Zhang, Z. and Suseela. V. (2021) Nitrogen Availability Modulates the Impacts of Plant Invasion on the Chemical Composition of Soil Organic Matter. Soil Biology and Biochemistry, 156, Article ID: 108195.

https://doi.org/10.1016/j.soilbio.2021.108195

[48] Salgado Salomón, M.E., Barroetaveña, C. and Rajchenberg, M. (2013) Pseudotsuga menziesii Invasion in Native Forests of Patagonia, Argentina: What About Mycorrhizas? Acta Oecologica, 49, 5-11. https://doi.org/10.1016/j.actao.2013.01.018

[49] Salgado Salomón, M.E., Barroetaveña, C., Pildain, M.B., Williams, E.A. and Rajchenberg, M. (2018) What Happens to the Mycorrhizal Communities of Native and Exotic Seedlings When Pseudotsuga menziesii Invades Nothofagaceae Forests in Patagonia, Argentina? Acta Oecologica, 91, 108-119.

https://doi.org/10.1016/j.actao.2018.07.003

[50] Stanek, M., Piechnik, L. and Stefanowicz, A.M. (2020) Invasive Red Oak (Quercus rubra L.) Modifies Soil Physicochemical Properties and Forest Understory Vegeta- 
tion. Forest Ecology and Management, 472, Article ID: 118253. https://doi.org/10.1016/j.foreco.2020.118253

[51] Zubek, S., Kapusta, P., Stanek, M., Woch, M.W. Błaszkowski, J. and Stefanowicz, A.M. (2022) Reynoutria japonica Invasion Negatively Affects Arbuscular Mycorrhizal Fungi Communities Regardless of the Season and Soil Conditions. Applied Soil Ecology, 169, Article ID: 104152. https://doi.org/10.1016/j.apsoil.2021.104152

[52] Lazzaro, L., Mazza, G., d'Errico, G., Fabiani, A., Giuliani, C., Inghilesi, A.F., et al. (2018) How Ecosystems Change Following Invasion by Robinia pseudoacacia: Insights from Soil Chemical Properties and Soil Microbial, Nematode, Microarthropod and Plant Communities. Science of the Total Environment, 622-623, 1509-1518. https://doi.org/10.1016/j.scitotenv.2017.10.017

[53] Stefanowicz, A.M., Zubek, S., Stanek, M., Grześ, I.M., Rożej-Pabijan, E., Błaszkowski, J. and Woch, M.W. (2019) Invasion of Rosa rugosa Induced Changes in Soil Nutrients and Microbial Communities of Coastal Sand Dunes. Science of the Total Environment, 677, 340-349. https://doi.org/10.1016/j.scitotenv.2019.04.408

[54] Dawkins, K. and Esiobu, N. (2018) The Invasive Brazilian Pepper Tree (Schinus terebinthifolius) is Colonized by a Root Microbiome Enriched with Alphaproteobacteria and Unclassified Spartobacteria. Frontiers in Microbiology, 9, Article No. 876. https://doi.org/10.3389/fmicb.2018.00876

[55] Nickerson K. and Flory S. L. (2015) Competitive and Allelopathic Effects of the Invasive Shrub Schinus terebinthifolius (Brazilian Pepper Tree). Biological Invasions, 17, 555-564. https://doi.org/10.1007/s10530-014-0748-4

[56] Morgan, E.C. and Overholt, W.A. (2005) Potential Allelopathic Effects of Brazilian Pepper (Schinus terebinthifolius Raddi, Anacardiaceae) Aqueous Extract on Germination and Growth of Selected Florida Native Plants. Journal Torrey Botanical Society, 132, 11-15. https://doi.org/10.3159/1095-5674(2005)132[11:PAEOBP]2.0.CO;2

[57] Wang, O., Jiang, K., Liu, J., Zhou, J. and Wu, B. (2018) Moderate and Heavy Solidago canadensis L. Invasion are Associated with Decreased Taxonomic Diversity But Increased Functional Diversity Of Plant Communities in East China. Ecological Engineering, 112, 55-64. https://doi.org/10.1016/j.ecoleng.2017.12.025

[58] Sun, Z.K. and He, W.M. (2010) Evidence for Enhanced Mutualism Hypothesis: Solidago canadensis Plants from Regular Soils Perform Better. PLoS ONE, 5, Article ID: e15418. https://doi.org/10.1371/journal.pone.0015418

[59] Li, Y., Laborda, P., Xie, X., Zhou, R., Chen, Y., Li, T., et al. (2020) Spartina alterniflora Invasion Alters Soil Microbial Metabolism in Coastal Wetland of China. Estuarine, Coastal and Shelf Science, 245, Article ID: 106982. https://doi.org/10.1016/j.ecss.2020.106982

[60] Liang, X., He, C., Zhu, X., Chen, X., Lei, Y., Zhang, H., Qin, Z. and Qi, X. (2016) Effect of Exotic Spartina alterniflora on Fungal Symbiosis with Native Plants Phragmites australis and Scirpus mariqueter, and Model Plants Lolium perenne L. and Trifolium repens. Aquatic Botany, 130, 50-58. https://doi.org/10.1016/j.aquabot.2015.10.003

[61] Nielsen, J.A., Whigham, P.A., Frew, R.D., Callaway, R.M. and Dickinson, K.J.M. (2014) Invasion Essentials: Does Secondary Chemistry Plasticity Contribute to the Invasiveness of Thymus vulgaris L.? Chemoecology, 24, 15-27. https://doi.org/10.1007/s00049-013-0142-1

[62] Si, C., Liu, X., Wang, C., Wang, L., Dai Z., Qi, S. and Du, D. (2013) Different Degrees of Plant Invasion Significantly Affect the Richness of the Soil Fungal Community. PLoS ONE, 8, Article ID: e85490. 
https://doi.org/10.1371/journal.pone.0085490

[63] Hebel, C.L., Smith, J.E. and Cromack, K. (2009) Invasive Plant Species and Soil Microbial Response to Wildfire Burn Severity in the Cascade Range of Oregon. Applied Soil Ecology, 42, 150-159. https://doi.org/10.1016/j.apsoil.2009.03.004

[64] Yang, B., Zhang, X., Zagorchev, L., Li, J., Frey, B. and Li, M. (2019) Parasitism Changes Rhizospheric Soil Microbial Communities of Invasive Alternanthera philoxeroides, Benefitting the Growth of Neighboring Plants. Applied Soil Ecology, 143, 1-9. https://doi.org/10.1016/j.apsoil.2019.05.025

[65] Perkins, L.B. and Hatfield, G. (2016) Can Commercial Soil Microbial Treatments Remediate Plant-Soil Feedbacks to Improve Restoration Seedling Performance? Restoration Ecology, 24, 194-201. https://doi.org/10.1111/rec.12302

[66] Kennedy, A.C. (2018) Selective Soil Bacteria to Manage Downy Brome, Jointed Goatgrass, and Medusahead and Do No Harm to Other Biota. Biological Control, 123, 18-27. https://doi.org/10.1016/j.biocontrol.2018.05.002

[67] Kremer, R.J., Caesar, A.J. and Souissi, T. (2006) Soilborne Microorganisms of Euphorbia are Potential Biological Control Agents of the Invasive Weed Leafy Spurge. Applied Soil Ecology, 32, 27-37. https://doi.org/10.1016/j.apsoil.2004.12.009

[68] Fang, K., Miao, Y.F., Chen, L., Zhou, J., Yang, Z.P., Dong, X.F. and Zhang, H.B. (2019) Tissue-Specific and Geographical Variation in Endophytic Fungi of Ageratina adenophora and Fungal Associations with the Environment. Frontiers in Microbiology, 10, Article No. 2919. https://doi.org/10.3389/fmicb.2019.02919

[69] Dai, Z-C., Fu, W., Wan, L-Y., Cai, H-H., Wang, N., Qi, S.-S. and Du, D.-L. (2016) Different Growth Promoting Effects of Endophytic Bacteria on Invasive and Native Clonal Plants. Frontiers in Plant Science, 7, Article No. 706. https://doi.org/10.3389/fpls.2016.00706

[70] Rodrigues, R.R., Pineda, R.P., Barney, J.N., Nilsen, E.T., Barrett, J.E. and Williams, M.A. (2015) Plant Invasions Associated with Change in Root-Zone Microbial Community Structure and Diversity. PLoS ONE, 10, Article ID: e0141424. https://doi.org/10.1371/journal.pone.0141424

[71] Zhu, X., Zhang, J. and Ma, K. (2011) Soil Biota Reduce Allelopathic Effects of the Invasive Eupatorium adenophorum. PLoS ONE, 6, Article ID: e25393. https://doi.org/10.1371/journal.pone.0025393

[72] Klimek, B., Jaźwa, M., Gołębiewski, M., Sikora, M. and Deja-Sikora, E. (2020) No Apparent Effect of Invasive Alien Goldenrod on Soil Microbial Communities or Soil Fauna Feeding Activity. Acta Oecologica, 109, Article ID: 103669. https://doi.org/10.1016/j.actao.2020.103669

[73] Birnbaum, C. and Leishman, M.R. (2014) Do Soil Microbes Drive Acacia Species Invasion in Non-Native Ranges in Australia? Biodiversity and Vegetation: Patterns, Processes, Conservation: 57 th Annual Symposium of the International Association for Vegetation Science, Perth, 1-5 September 2014. 